\title{
MEDIA COVERAGE AND STOCK RETURN IN THE TAIWAN STOCK MARKET
}

\author{
Kuei-Yuan WANG ${ }^{1}$ - Chien-Kuo CHEN ${ }^{2}$ - Hsiao-Chi WEI ${ }^{3}$ \\ ${ }^{I}$ Department of Finance, Asia University, 500, Lioufeng Rd., Wufeng, Taichung 41354, \\ Taiwan, R.O.C.; \\ Department of Medical Research, China Medical University Hospital, \\ China Medical University, 2 Yude Road, Taichung 40402, Taiwan, R.O.C. \\ E-mail: gueei5217@gmail.com (corresponding author)
}

${ }^{2}$ Taiwan Knowledge Bank, 3F., 60, Bo'ai Rd., Zhongzheng Dist., Taipei City 10041, Taiwan, R.O.C. E-mail: alexchen1980@pchome.com.tw

${ }^{3}$ Dadu Elementary School, 77, Huashan Rd., Dadu District, Taichung City 432-52, Taiwan, R.O.C.E-mail:paniclx@gmail.com

The purposes of this paper were to explore the relationship between media coverage and stock returns in Taiwan stock markets. The empirical results were as follows: (1) stock returns showed causality with either media coverage amounts or the degrees of good/bad media coverage; (2) when impacted by the past stock returns, the stock return might finish its response to the impulse around three days and showed a negative effect, whereas when impacted by the past media coverage amounts, the media coverage amount might also finish its response to the impulse within three day and showed a negative effect; (3) when impacted by the degrees of the past good media coverage, the good media coverage degree might finish its response in three days and showed a negative effect, in which a positive effect might be presented on the first two days, while the effect might turn negative on the third day. Given that, when impacted by the past stock returns, the stock return might finish its response to the impulse within three days and showed a negative effect and, when impacted by the degrees of the past good media coverage, the stock return might also finish its response in three days and showed a negative effect. That is, media coverage could be used as an indicator to predict stock returns in the Taiwan stock markets when making investment decisions.

Keywords: media coverage, stock return, impulse response analysis

\section{INTRODUCTION}

According to Chen and Meindl (1991), Shiller (2001) and Carroll and McCombs (2003), in addition to acting as an event broadcaster, mass media could also assimilate and disseminate broadcast ideas, further affect the public's behavior and, in the end, dominate their perception of the company in question. Furthermore, some academics also verified that media coverage could result in the announcement effect of a company's significant event (Stephens and Weisbach 1998; Sherman 
and Titman 2002; Liu et al. 2007). As such, other than influencing the public's perception, media are also closely associated with economic activities.

Cutler et al. (1989) investigated the relationship between media coverage and stock prices, their results showed that the impact of major event on stock prices could not be fully explained by media coverage. Chan (2003) further found that investors might underreact to bad news coverage. Tetlock (2007) also found that, when a company's fundamentals reversed, the higher pessimistic sentiment of the media could predict the downward pressure of the stock market. Moreover, Tetlock et al. (2008) also considered media coverage an important qualitative variable to capture the part difficult to be quantified through a company's fundamentals, especially the tendency that stock prices might underreact to the message implied negative meaning. According to Engelberg et al. (2012), higher audience ratings could result in higher inter-day returns. However, if investors are recommended to adopt a sell-out strategy, it will lead to a weak price effect. On the other hand, if investors concurrently buy or sell the stocks as recommended on a program, the empirical result sustained the retail attention hypothesis put forth by Barber and Odean (2008), i.e. media might potentially influence stock prices, which would make stocks mispriced. Fang and Peress (2009) discovered that the stocks without media coverage could have higher stock returns in the future than those that have higher media exposure.

To sum up, media coverage could have an influence on stock markets. Hence, this study tried to further explore the causality between media coverage and stock returns as well as the impulse response effect. Different from the Western markets, Taiwan's stock market mostly comprised by retail investors rather than institutional investors. Hence, in addition to providing the results of the research on such kind of markets to complement what is insufficient in literature, the study also hoped to offer investors the empirical results as the indicator for their application of media coverage amounts and good/bad news coverage to their investment decision making, i.e. how to turn media coverage into an indicator of investment decision making.

The rest of this study was organized as follows. Section 2 was the literature review, whereas Section 3 showed the methodology of this study. Section 4 was the empirical results. The final part showed the conclusions and recommendations.

\section{LITERATURE REVIEW}

A body of literature showed that information could be transmitted through mass media (Islam 2002; Borden 2007), and mass media could further affect the public's perception. According to the "agenda setting theory" proposed by McCombs 
and Shaw (1972), media could produce an issue which would make a splash and draw the limelight, of which the coverage amount and coverage size would determine the importance of the issue as perceived by the public. Furthermore, Chen and Meindl (1991), Shiller (2001) and Carroll and McCombs (2003) also thought that, other than simply broadcasting an event, mass media could also assimilate and broadcast the conception to affect the general public's ensuing behavior and further influence their perception of the company in question. Some literature also verified that media coverage could affect announcement effect of a company's major event. Stephens and Weisbach (1998), Sherman and Titman (2002) and Liu et al. (2007) also pointed out that mass media could not only affect the thoughts of the public, but also further generate the ignorable strength of a company. As such, media coverage and economic activities are closely related, and media coverage could also directly or indirectly influence economic activities (Shieh 2014).

However, in a stock market where transactions are more active and message spreading is more aggressive, a company's fundamental information can no longer be used to explain changes in stock prices ( $\mathrm{Li}$ and Yen 2011). Hence, the noise trading theory mentioned by Kyle (1985) and Black (1986) argued that investors might use the corporate information received by themselves (although the information might not be true) as the reference for their transactions, which could result in over volatility of stock prices. In other words, investors cannot acquire inside information and, instead, they irrationally use the noise information as useful information in their transactions. Engelberg and Parsons (2012) also used different types of information to identify the degrees of media effect. It explored varying kinds of media coverage with a same event, and found that local media coverage could lead to increase of local investors' trading volume. It shows that media coverage could affect investment activities. Hence, the study then explored the literature of the effect of past media coverage on stock values as follows.

\subsection{Relationship between media coverage and stock prices}

The first paper to mention about media coverage and stock price could be dated back to the one conducted by Cutler et al. (1989), which investigated S\&P 500 indices from 1941 to 1987 . By probing the factors in change of stock prices, their empirical results suggested that the effect of the major event in the market on stock prices could not be completely explained from media coverage. Afterwards, the studies related to the relationship between media coverage and stock prices have continued to be released. 
Dyck and Zingales (2003) also examined the stock market response effect through the earnings announcement reported by the media and investigated if media coverage could affect stock prices. They found that the stock prices of those companies that were specifically stressed by the media reporters showed the biggest impulse response, in which if a company was less mentioned by analysts, the media coverage could turn out to be more trusted by investors. Hence, Dyck and Zingales (2003) thought that media played an important role in releasing information. Vega (2006) also suggested that information could have significant impact on the U.S. stock market, illustrating that it does not matter whether it is opening or private information and what matters most is the speed of the transmission of relevant information to the investors who may or may not know the veracity of the information.

Klibanoff et al. (1998) examined the response of the investors investing in closed-end funds to the major event, and found that if the news of a specific country was headlined by the New York Times, it could further affect the pricing of the country's closed-type funds. Even though volatility of stock prices could be measured by the latest information on a company's fundamentals, investors would still swiftly respond to the major event headlined by the New York Times, which would further lead to volatility of stock prices. Hence, Klibanoff et al. (1998) contended that media coverage could accelerate investors' response.

Engelberg et al. (2012) examined the direct measurement indicator of investors' attention with Nielson's survey data. They found that when audience ratings were high, the inter-day return could attain the peak; when sell-out was suggested on a program, the weak price effect would show up; when concurrently considering the suggestion of both buy-in and sell-out. The empirical results sustained the "retail attention hypothesis" put forth by Barber and Odean (2008), which was to emphasize the attention paid by retail investors and institutional investors in their purchase behavior as well as news effect, and illustrate media's potential role in resulting in mispricing.

\subsection{Relationship between media coverage amounts and stock prices}

Buskirk (2006) used the words of the media coverage accumulated during the event period as the rule to judge the strength of news disclosure, followed the rule to observe the density of investors' approach to the information. They explored the relationship between the number of the news words and stock returns, and found that excepted returns and trading volume showed a significant and positive correlation with the number of accumulated words of media coverage. In their studies on the relationship between stock return and the amount of the 
media coverage on the stock in question, Holden and Subrahmanyam (1992), Foster and Viswananthan (1990), and Brennan et al. (1993) also found that those portfolios frequently analyzed and reported by the media could be more sensitive to released information.

Antweiler and Frank (2004) had a series of study on the effect of exposure of a news event on stock prices, and thought that investors would go online to release or solicit opinions before or after their selection of a stock. Hence, they investigated the effect of the amounts of the stock information left on Internet message boards on investors' decision making. The results showed that the amounts of the stock information left on Internet message boards and trading volume had a significantly positive correlation with the degrees of price volatility. Antweiler and Frank (2006) further discovered that, about 10 days after the news release, the stock return could significantly reverse, which was interpreted as investors' overreaction to the news. Fang and Peress (2009) explored the relationship between media focus and stock returns, and found that the degree of media focus on an individual stock showed a negative correlation with the stock's future performance, of which the stock receiving less media focus would be likely to have a significantly higher return in the future.

After having interviewed 7,000 CEOs from 1997 to 2006 at CNBS, Kim and Meschke (2011) investigated if media focus would affect stock prices and trading volume, and found that a higher trading volume and significantly normal/exceptional return could occur on the interviewing day. However, such tendency could intensely reverse in the following 10 transaction days, of which the exceptional return would be relatively greater if more audience watched the program. It was also found that retail investors would follow the interview content to determine their trading behavior.

Da et al. (2011) used the frequency of the search volume index provided by Google as the reference for investors' attention to stocks. They found that the frequency was associated with the proxy variable concerned by those who represented the investor previously, i.e. the price of a stock having a higher search frequency would be likely to be propelled in the two weeks to come.

When exploring the relationship between stock prices and media coverage in corporate merger and acquisition, Ahern and Sosyura (2012) pointed out that enterprises would make good use of media coverage to influence their stock prices when a major event occurs. Those enterprises would release plenty of news after beginning their negotiation for stock acquisition and before making the acquisition announcement, which would result in a short-term rise of the bidding stocks, and apparently affect stock prices. They suggested that the reporting time and content of financial media coverage could have some biases as a result of enterprises' manipulation of their stock prices. 


\subsection{Relationship between positive/negative news coverage and stock prices}

Nofsinger (2001) considered that institutional and individual investors could be greatly affected by media coverage on financial information. It would be especially so for the information regarding earnings announcement, for which either positive or negative information would affect institutional investors' investment behavior, while individual investors would only be influenced by positive news. Barberis et al. (1998) analyzed the phenomenon of stock price reversal with the momentum and contrarian strategy. It indicated that while facing new information which would be associated with a company's stock price, such as earnings announcement, investors would first have some doubt about it, and therefore show an underreaction behavior. In this case, investors could cash in on the stock market anomaly and adopt the zero-cost momentum strategy to gain profits. When good news of a company continued to be diffused to investors, investors would have optimistic opinions on the company which would bring about an overestimation of the company's stock price. However, such overestimation would not continue. In the end, the stock price would return to the fundamental value it deserved.

By adopting the event study analysis, Chan (2003) explored investors' response to the release of the news on stock prices, in which the samples were divided into two groups of publication and non-publication according to whether a company's stock related information was published as headline news in the current month. They sorted the samples whose stock related information was published as the headline news by stock returns, and divided into a 10-point scale, where those companies that fell in the top $30 \%$ were defined as winners and the last $30 \%$ were losers, and varying portfolios were formed according to different formation periods and holding periods. They found that, after exposure of the positive (negative) news, stock prices would continue to respond in a positive (negative) direction, and the response to negative news could last longer (as long as 12 months). They suggested that investors seemed to have strong underreaction on bad news; however, for the portfolios having no media coverage, the stock prices showed reversal.

Tetlock (2007) tried to investigate the relationship between media content and daily stock market activities and found that, compared with other kinds of wording, negative wording could result in stronger impulse to stock returns. In addition, exceptional large or small amount of media negative coverage could be used to predict smaller or larger trading volume. The empirical result sustained that the content of media coverage could be deemed the proxy variable of investor sentiment or the trading made by those who did not have the information. Tetlock et al. (2008) pointed out that linguistic communication was a potential important infor- 
mation source for a company's fundamental value, and the three main dimensions used by investors for investigating listed companies were: analysts' forecast, publicly disclosed accounting variables and the linguistic variables which could create profits currently or in the future. If the former two dimensions were not complete or a company's fundamentals were deviated, linguistic variables could be additionally explained as the strength of a company's future earnings and returns. The empirical results suggested the following: (1) negative wording could transmit a negative message on decrease in accounting reports as forecasted by analysts or according to historical records; (2) a stock's market price would be less impacted by the assets hidden in negative wording and the impulse response would be delayed for one day; (3) the content of linguistic media coverage could capture a company's fundamental information which would be hard to be quantified in investors' rapid response to stock prices.

Barber and Odean (2008) explored investors' proxy behavior from three sectors of trading volume, exceptional returns and positive/negative news, and found that investors were more likely to buy the popular stocks with high trading volume, extremely excepted returns and high media disclosure. Barber and Odean (1998) found that investors would put more focus on the information they learned. Barber and Odean (2001) further found that when a company's news was more frequently released in the Wall Street Journal on a same day, investors would be more interested in the news and further purchase the company's stock. According to Barber and Odean (2011), it was found that investors were even not able to make a decision out of so many pieces of information, so they would mostly purchase the popular stocks more widely reported by the media. In addition, retail investors would be more susceptible than institutional investors and more likely to overreact to the information.

By studying the effect of financial column articles on stock prices, Dougal et al. (2011) thought that those columnists had their own preference in judging the performance of stock markets. Some tended to have a bullish outlook on the market, while others liked to have a bearish outlook. Hence, those columnists were divided into two categories of optimism and pessimism. Dougal et al. (2011) suggested that the specific sentiment of those columnists could cause volatility of market prices. It shows that the media effect may lead to price deviation from a stock's fundamental value.

To sum up, media coverage might affect stock prices, and the amount of media coverage had positive correlation with the stock return. However, the empirical result for the relationship between the amounts of media coverage and future stock returns showed inconsistent. By further exploring the effect of the positive/ negative message of media coverage on stock returns, it was found that a negative message could have a greater effect on stock prices. 


\section{METHODOLOGY}

\subsection{Data and sample}

This study used the stocks of TSEC-listed companies as samples from October 2, 2000 to December 31, 2012. After eliminating the companies that suffered financial crises, data of stock returns came from the Taiwan Economic Journal (TEJ) database, while its media coverage data were from the CMoney database. Given that the media coverage data were not available until October 2, 2001, the empirical period was somewhat restrained. As for the choice of data frequency, this study followed Tetlock (2007) and Tetlock et al. (2008) to adopt daily data, in which the daily data were also applied to the data frequency of stock returns.

\subsection{Model}

\subsubsection{Vector auto-regression analysis}

This study followed Tetlock's (2007) vector auto-regression (VAR), in which independent variables lagged for five periods. The VAR models were as follows:

$$
\begin{aligned}
& \left\{\begin{array}{l}
\text { Return }_{t}=\alpha+\sum_{j=1}^{5} \text { Return }_{t-j}+\Sigma_{j=1}^{5} \text { amount }_{t-j}+\varepsilon_{i, t} \\
\text { amount }_{t}=\alpha+\Sigma_{j=1}^{k} \text { Return }_{t-j}+\Sigma_{j=1}^{5} \text { amount }_{t-j}+\varepsilon_{i, t}
\end{array}\right. \\
& \left\{\begin{array}{l}
\text { Return }_{t}=\alpha+\Sigma_{j=1}^{5} \text { Return }_{t-j}+\Sigma_{j=1}^{5} \text { bullbear }_{t-j}+\varepsilon_{i, t} \\
\text { amount }_{t}=\alpha+\Sigma_{j=1}^{k} \text { Return }_{t-j}+\Sigma_{j=1}^{5} \text { bullbear }_{t-j}+\varepsilon_{i, t}
\end{array}\right.
\end{aligned}
$$

where Return ${ }_{t}$ represents stock return; $n_{t-j}$ is the total of media coverage on the jday; bullbear ${ }_{\mathrm{t}-\mathrm{j}}$ is the strength of good/bad news on the jday; the strength of good/ bad news is somewhere between $-100 \%$ and $100 \%$ mainly based on the content of the media coverage with the natural linguistic method. If the ratio of the media positive wording is higher, the score will be closer to $100 \%$. On the contrary, if the media negative wording takes a higher ratio, the score will be closer to $-100 \%$. Mass positive wording signals stronger good news, whereas mass negative wording represents stronger bad news. 


\subsubsection{Impulse response analysis}

Impulse response analysis is used to track the continuation of unexpected change in dependent variables against other variables, so as to analyze the dynamic effect of the change of an error term or the impulse of a model on the system, which is also called the impulse response function. The response analysis may show the response of the dependent variable to the impulse of each variable, the effect (positive or negative) among variables, the length of the influence time and the influence degree. Hence, by giving a unit of impulse to the error term of each variable in each equation, it will yield the effect of the impulse on the VAR system in a period of time. The equation was as follows:

$$
x_{t}=\alpha+\Sigma \beta_{i} \varepsilon_{t-i}+\varepsilon_{t}
$$

where is the impulse response function.

\section{EMPIRICAL RESULTS}

\subsection{Descriptive statistics}

Table 1 showed the descriptive statistic data of the study. The average daily stock return is 0.0004 , whereas the standard deviation is 0.0370 . When observing the standard deviation of stock return, the maximum value is 0.0921 and the minimum one is -0.8931 , which showed that the return rates were not diffusive. In the aspect of media coverage amounts, the average media coverage amount was 0.9292 , the standard deviation was 2.0391, the maximum value was 72 and the minimum one was 0 . It illustrated that media coverage amounts were more concentrated. The average good/bad news strength was 6.0996, the standard deviation was 22.8895 , the maximum value was 100 and the minimum one was -100 .

Table 1. Descriptive statistics

\begin{tabular}{lccccc}
\hline Variable & $\mathrm{N}$ & Mean & Std. & Min & Max \\
\hline Return & $1,979,701$ & 0.0004 & 0.0370 & -0.8931 & 0.0921 \\
Amount & $1,979,701$ & 0.9292 & 2.0391 & 0 & 72 \\
Bullbear & $1,979,701$ & 6.0996 & 22.8895 & -100 & 100 \\
\hline
\end{tabular}

Note: return represented the stock return; $\mathrm{n}$ represented the media coverage amount; bullbear represented the good or bad degree of the media coverage. 


\subsection{Augmented Dickey-Fuller (ADF) unit root test}

Before VAR analysis, the study conducted an ADF unit root test, and the empirical results indicated that the stock return, media coverage amount and good/ bad news strength all reached $1 \%$ statistical significance level (the $t$ values were $-464.4133,-208.6836$ and -340.3537 , respectively) in the ADF unit root test. Hence, the three series were all listed as the stationary series.

\subsection{Granger causality tests}

\subsubsection{The Granger causality test of stock returns and media coverage amounts}

According to the study's causality test of stock returns and media coverage amounts, the p-values all reached 1\% statistical significance level (the chi-square values were 129.8789 and 358.0865 respectively). It showed that, according to the Granger causality, media coverage amounts might affect stock returns and stock returns may also affect media coverage amounts. In other words, both of them were in an interactive relationship.

\subsubsection{Causality test of the stock returns and good/bad news}

For the causality test of stock returns and good/bad news strength, the p-values all reached 1\% statistical significance level (the chi-square values were 622.7661 and 7801.086, respectively). It showed that, according to the Granger causality, good/bad news strength may affect stock returns and stock returns might also affect good/bad news strength. As such, both of them were in an interactive relationship.

\subsection{VAR analysis}

\subsubsection{VAR analysis of media coverage amounts and stock returns}

Table 2 used stock return and media coverage amounts, respectively, as dependent variables. This study used the VAR model to investigate the relationship between explained and explanatory variables, in which 5 periods of lagged days were adopted. According to the empirical results shown in Table 2, if the dependent variable was the stock return, the F-value was 60.73 . By individually inspecting 
Table 2. The VAR analysis of stock return and media coverage amount

\begin{tabular}{lcc}
\hline & Return & Amount \\
\hline$\alpha$ & $0.0004 \quad * * *$ & $0.2528 \quad * *$ \\
& $(13.69)$ & $(173.74)$ \\
Return (-1) & $0.0539 \quad * * *$ & $0.5705 \quad * * *$ \\
& $(75.77)$ & $(17.17)$ \\
Return (-2) & $0.0024 \quad * * *$ & 0.0152 \\
& $(3.41)$ & $(0.46)$ \\
Return (-3) & $-0.0014 \quad * *$ & $-0.1053 \quad * *$ \\
& $(-2.00)$ & $(-3.16)$ \\
Return (-4) & $-0.0070 \quad * * *$ & -0.0539 \\
& $(-9.80)$ & $(-1.62)$ \\
Return (-5) & 0.0003 & $-0.1020 * * *$ \\
& $(0.47)$ & $(-3.07)$ \\
\hline Amount (-1) & $0.0001 \quad * * *$ & $0.2767 \quad * * *$ \\
& $(6.48)$ & $(392.42)$ \\
Amount (-2) & $-0.0001 \quad * * *$ & $0.1071 \quad * * *$ \\
& $(-3.74)$ & $(147.00)$ \\
Amount (-3) & 0.0000 & $0.1070 \quad * * *$ \\
Amount (-4) & $(0.63)$ & $(146.87)$ \\
Amount (-5) & $0.0000 \quad * *$ & $0.1056 * * *$ \\
& $(2.46)$ & $(145.00)$ \\
\hline F-value & $-0.0001 \quad * * *$ & $0.1315 * * *$ \\
adj $\mathrm{R}^{2}$ & $(-9.14)$ & $(86.47)$ \\
\hline
\end{tabular}

Note: return represented the stock return; amount represented the amount of media coverage. The parentheses denoted the $\mathrm{p}$-value. ${ }^{*} \mathrm{P}<0.05, * * \mathrm{p}<0.01, * * * \mathrm{p}<0.001$

the effect of the number of the lag days on the stock return of the current period, the empirical results showed that the stock return of the current period was significantly and positively affected by the amounts of media coverage in the past $1^{\text {st }}$ and $4^{\text {th }}$ periods (amount [-1] and amount [-4]), but is significantly negatively influenced by the amounts of media coverage in the past $2^{\text {nd }}$ and $5^{\text {th }}$ periods (amount [-2] and amount [-5]). On the other hand, the stock return of the current period is significantly positively affected by the stock returns of the past $1^{\text {st }}$ and $2^{\text {nd }}$ periods (return [-1] and return [-2]), but is significantly negatively affected by the stock returns of the past $3^{\text {rd }}$ and $4^{\text {th }}$ periods (return [-3] and return [-4]).

In view of the effect of lag period's media coverage amounts on stock returns, the stock return was significantly positively affected by the amount of the media coverage on the $1^{\text {st }}$ day of the lag period, i.e., the more the media coverage 
amount on the $1^{\text {st }}$ day of the lag period was, the higher the stock return on that day would be. However, the stock return on the $2^{\text {nd }}$ day of the lag period showed negative significance, on the $4^{\text {th }}$ day, it came back to be significantly positive and, on the $5^{\text {th }}$ day, it turned to be significantly negative again. It illustrated that, as affected by the amounts of media coverage after the $2^{\text {nd }}$ day of the lag period, stock returns continued to show a reversal phenomenon.

In addition, the empirical results showed that, when the independent variable was the media coverage amount, the F-value was 78.04. By individually inspecting the effect of the number of the lag days on the media coverage amount of the current day, the empirical results showed that the media coverage amount of the current day was significantly positively affected by the stock return on the past $1^{\text {st }}$ day (return [-1]), but was significantly negatively affected by the stock returns in the past $3^{\text {rd }}$ and $5^{\text {th }}$ periods (return [-3] and return [-5]). On the other hand, the media coverage amount of the current period was significantly positively affected by the stock returns of the past $1^{\text {st }}, 2^{\text {nd }}, 3^{\text {rd }}, 4^{\text {th }}$ and $5^{\text {th }}$ periods (amount [-1], amount [-2], amount [-3], amount [-4] and amount [-5]).

In view of the effect of stock returns in the lag period on the amounts of media coverage, the media coverage amount was significantly positively affected by the stock return on the $1^{\text {st }}$ day of the lag period, i.e. the higher the stock return on the $1^{\text {st }}$ day of the lag period was, the more the media coverage amount on that day would be. However, the stock return on the $2^{\text {nd }}$ day of the lag period showed a positive and insignificant effect; on the $3^{\text {rd }}$ day, it showed a significantly negative effect; on the $4^{\text {th }}$ day, it showed an insignificantly negative effect; on the $5^{\text {th }}$ day, it showed a significantly negative effect. It illustrated that stock returns in the lag period could affect the amounts of media coverage, but after the reversal on the $3^{\text {rd }}$ day of the lag period, the reversal continued.

\subsubsection{VAR analysis of good/bad news strength and stock returns}

As shown in Table 3, stock returns and good/bad news strength of media coverage were used as the independent variables for exploring their relationship with the explanatory variables of the lag period. The study used the VAR model to do the investigation, in which 5 periods of deferred days were adopted. According to the empirical results shown in Table 3, if the independent variable was the strength of good/bad news coverage, the F-value was 65.60 . By individually inspecting the effect of the stock returns in the lag days on the current period stock return, the empirical results showed that, as affected by the stock returns on the past $1^{\text {st }}$ and $2^{\text {nd }}$ day (return [-1] and return [-2]), the current period stock return showed a significantly negative effect. However, it showed a significantly negative effect 
Table 3. The VAR analysis of stock return and degrees of good/bad media coverage

\begin{tabular}{lcc}
\hline & Return & Bullbear \\
\hline$\alpha$ & $0.0002 * * *$ & $45.0125 * * *$ \\
& $(8.30)$ & $(2470.44)$ \\
Return (-1) & $0.0525 * * *$ & $18.8539 * * *$ \\
& $(73.54)$ & $(42.21)$ \\
Return (-2) & $0.0014 * * * 19^{*}$ & $7.1918^{* * *}$ \\
& $(1.90)$ & $(16.05)$ \\
Return (-3) & $-0.0020^{* * *}$ & $4.5451 * * *$ \\
& $(-2.78)$ & $(10.15)$ \\
Return (-4) & $-0.0075 * * *$ & $6.1356 * * *$ \\
& $(13.70)$ & $(13.70)$ \\
Return (-5) & 0.0001 & $7.3969 * * *$ \\
& $(0.18)$ & $(16.53)$ \\
\hline Bullbear (-1) & $0.0001 * * *$ & $0.0558 * * *$ \\
& $(23.18)$ & $(75.20)$ \\
Bullbear (-2) & -0.0000 & $0.0101 * * *$ \\
& $(-1.00)$ & $(13.45)$ \\
Bullbear (-3) & 0.0000 & $0.0050 * * *$ \\
& $(1.26)$ & $(6.72)$ \\
Bullbear (-4) & $0.0000 * * *$ & $0.0076 * * *$ \\
& $(3.42)$ & $(10.11)$ \\
Bullbear (-5) & $-0.0000 * * *$ & $0.0064 * * *$ \\
& $(-7.67)$ & $(8.69)$ \\
\hline F-value & $65.60 * * *$ & $154.9 * * *$ \\
Adj $\mathrm{R}^{2}$ & 0.033 & 0.058 \\
\hline
\end{tabular}

Note: return represented the stock return; bullbear represented the degrees of good/bad media coverage. The parentheses denoted the p-value. ${ }^{*} \mathrm{P}<0.05, * * \mathrm{p}<0.01, * * * \mathrm{p}<0.001$

as affected by the stock returns on the past $3^{\text {rd }}$ and $4^{\text {th }}$ days (return [-3] and return [-4]), presented a significantly positive effect as affected by the good/bad news coverage on the past $1^{\text {st }}$ and $4^{\text {th }}$ days (bullbear [-1] and bullbear [-4]) and indicated a significantly negative effect as affected by the good/bad news coverage on the past $5^{\text {th }}$ day (bullbear [-5]).

In view of the effect of lag period's good/bad news coverage on the stock return of the current period, the stock return of the current period was significantly positively affected by the good/bad news coverage on the past $1^{\text {st }}$ and $4^{\text {th }}$ days, i.e. the stronger the good/bad news coverage strength on the past $1^{\text {st }}$ and $4^{\text {th }}$ days was, the higher the stock return on the current day would be. However, the stock return on the past $5^{\text {th }}$ day showed a significantly negative effect and it presented insignificantly negative on the past $2^{\text {nd }}$ day, but indicated insignificantly positive on the past $3^{\text {rd }}$ day. 
In addition, the empirical results showed that, when the strength of the good/ bad news coverage was the independent variable, the F-value was 154.9. By individually inspecting the effect of the stock returns and the strength of the good/ bad news coverage in the lag period on the strength of current period good/bad news coverage, the empirical results showed that the good/bad news coverage of the current period was significantly positively affected by the stock returns on the past $1^{\text {st }}, 2^{\text {nd }}, 3^{\text {rd }}, 4^{\text {th }}$ and $5^{\text {th }}$ days (return [-1], return [-2], return [-3], return [-4], return [-5]), and also significantly positively affected by the good/bad news coverage on the past $1^{\text {st }}, 2^{\text {nd }}, 3^{\text {rd }}, 4^{\text {th }}$ and $5^{\text {th }}$ days (bullbear [-1], bullbear [-2], bullbear [-3], bullbear [-4], bullbear [-5]).

In view of the effect of stock returns on the strength of good/bad news coverage, the strength of good/bad news coverage was significantly positively affected by the stock returns on the $1^{\text {st }}$ to $5^{\text {th }}$ days of the lag period, indicating that the higher the stock return within the first five days of the lag period was, the higher the current day good/bad news coverage and the longer the effect of stock returns on good/bad news strength would be.

\subsection{Impulse response analysis}

\subsubsection{Stock return vs. amount of media coverage}

Figure 1 showed the impulse response analysis of stock returns (RETURN) and media coverage amounts $(\mathrm{N})$. When the impulse came from the stock return and the media coverage amount, respectively, it showed the change in response to the other variable. According to the empirical results, as impacted by the past stock returns, the stock return might finish its response to the impulse within three days, and showed a negative effect, whereas the data from the $4^{\text {th }}$ day to the $10^{\text {th }}$ days might show slow convergence in response.

When impacted by the past media coverage amounts, the media coverage amount might also finish its response to the impulse in about three days, and showed a negative effect, whereas the data might show slow convergence from the $4^{\text {th }}$ day to the $8^{\text {th }}$ day. However, some impulse response might reappear on the $9^{\text {th }}$ and $10^{\text {th }}$ days. Given that the media coverage amount might finish its response within three days and show a negative effect, whereas the data might show slow convergence from the $4^{\text {th }}$ day to the $10^{\text {th }}$ day, it illustrated that the diffusion speed of the information on stock returns was almost equivalent to that on media coverage. 

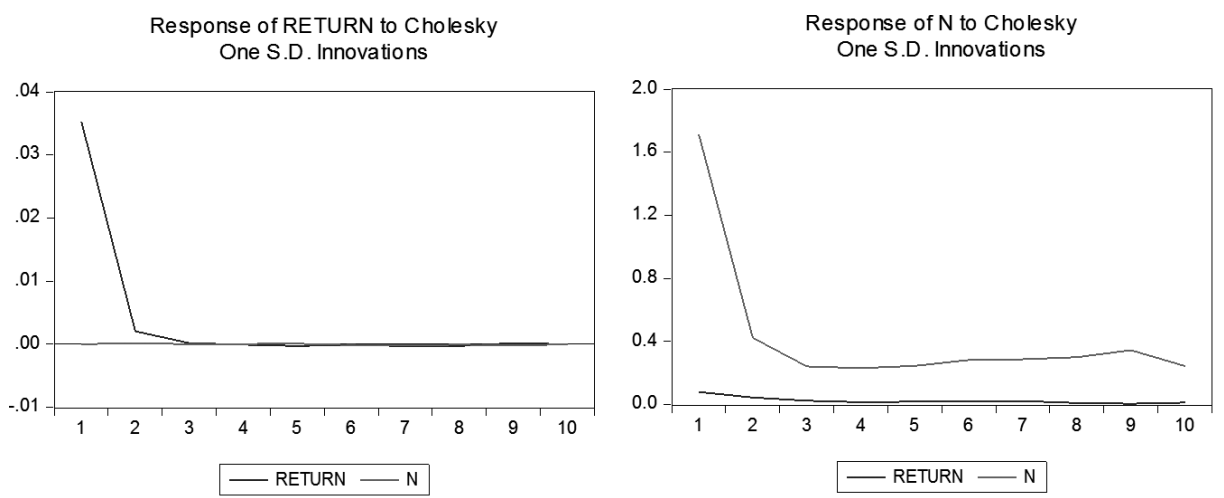

Figure 1. The impulse analysis of stock return and media coverage amount
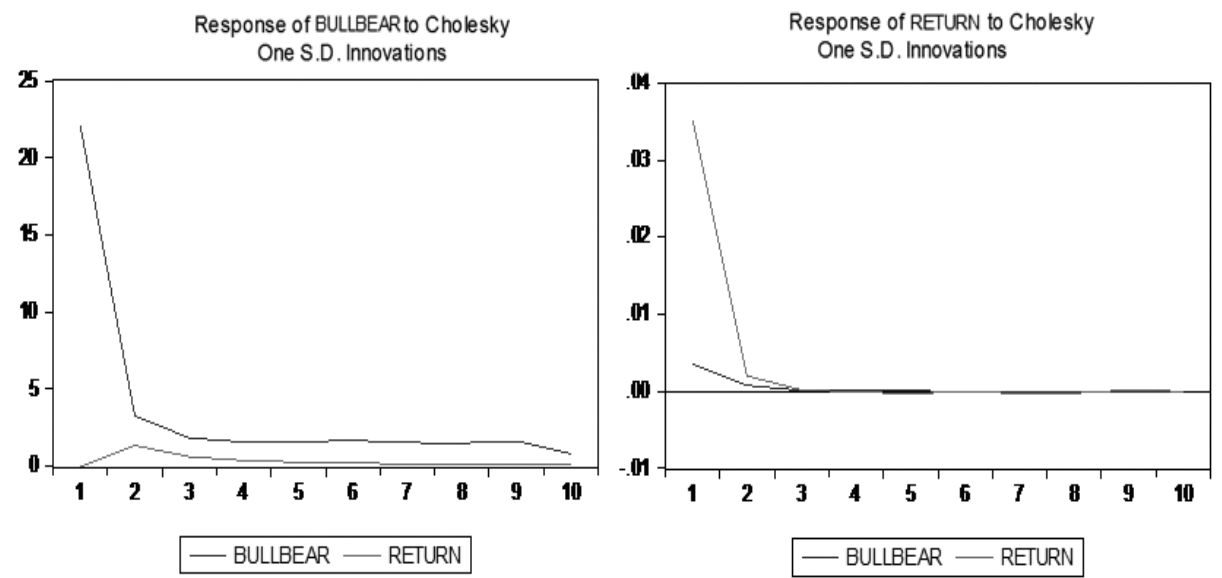

Figure 2. The impulse analysis of stock return and degrees of good/bad media coverage

\subsubsection{Stock return vs. good news level of media coverage}

Figure 2 shows the impulse response analysis of stock returns and the degrees of good news coverage. When the impulse came from the stock return and the degree of good news coverage, respectively, it showed change in response to the other variable. By observing the two variables, it was found that, when impacted by the past good news coverage degrees, the good news coverage degree might finish its response to the impulse within three days and showed a negative effect, whereas the data might show convergence by degrees from the $4^{\text {th }}$ day to the 
$8^{\text {th }}$ day. However, some negative effect might be found on the $9^{\text {th }}$ and $10^{\text {th }}$ days. Nevertheless, as impacted by the past stock returns, the degree of good news coverage showed a positive effect on the $1^{\text {st }}$ and $2^{\text {nd }}$ days, but it turned to a negative effect on the $3^{\text {rd }}$ day before starting converging.

When impacted by the past stock returns, the stock return might finish its response within three days and showed a negative effect, whereas the data might show convergence by degrees from the $4^{\text {th }}$ day to the $10^{\text {th }}$ day. Likewise, when impacted by the past good news coverage degrees, the stock return might finish its response to the pulse within three days and showed a negative effect, whereas the data might show convergence by degrees from the $4^{\text {th }}$ day to the $8^{\text {th }}$ day. It illustrates that the diffusion speed of the information on stock returns was almost equivalent to that on the degrees of good news coverage.

\section{CONCLUSIONS}

This study investigated the relationship between media coverage and stock returns with the samples selected from the stocks of TSEC-listed companies from October 2, 2000 to December 31, 2002. The empirical results suggested the following: (1) stock returns and media coverage amounts showed causality, in which the media coverage amounts on the past $1^{\text {st }}$ and $4^{\text {th }}$ days might show a significant and positive effect on the stock return of the current day. But the media coverage amounts on the past $2^{\text {nd }}$ and $5^{\text {th }}$ days might show a significant and negative effect on the stock return of the current day, while the stock return on the previous day might show a significant and positive correlation with the media coverage amount of the current day. The stock returns on the past $3^{\text {rd }}$ and $5^{\text {th }}$ days may show a significant and negative correlations with the media coverage amount of the current day; (2) stock returns and the degrees of good/bad news coverage show causality, in which if more good news was released in the media in the past $1^{\text {st }}$ and $4^{\text {th }}$ days, it would show a significant and positive effect on the stock return of the current period. However, if more good news was released on the past $5^{\text {th }}$ day in the media, it would show a more significant and negative effect on the stock return of the current period, whereas, if the stock return on the past $5^{\text {th }}$ day was higher, the media coverage of the current period would be more positive; (3) when impacted by the past stock returns, the stock return might finish its response to the impulse within three days and showed a negative effect. However, in the circumstance where the stock return is less impacted by the media coverage amount, if the media coverage amount is impacted by past amounts of media coverage, it might also finish its response to the impulse in about three days and show a negative effect; (4) when impacted by the degrees of the past good news 
coverage, the good news coverage degree might finish its response to the impulse in three days and showed a negative effect, in which a positive effect might be presented on the first two days, while the effect might turn negative on the third day. When impacted by the past stock returns, the stock return might finish its response to the impulse within three days and show a negative effect and, when impacted by the degrees of the past good news coverage, the stock return might finish its response to the impulse in three days and showed a negative effect.

Individual investors take the vast majority in Taiwan's stock markets, but, on the other hand, they are often the disadvantaged group in terms of their access to information. The study has verified that media coverage might significantly affect stock returns and it has provided individual investors with one more reference indicator for their investment decision making. Furthermore, although institutional investors have more information sources and are more capable of information analysis, the study can also offer institutional investors another important investment reference, so they can give more thorough analysis before making any investment decisions. As verified by this study that media coverage and stock returns are mutually affected, when using media coverage as the reference for investment decision making, please must also analyze the performance of stock returns. In addition, according to the impulse response analysis and forecast of the error variance, as opposed to media coverage amounts, the good/bad news degree has a greater value of effect on the stock return. It illustrated profound effect of information content on the stock return, which should not be neglected by investors.

The study also encountered some restrictions in the course of its investigation which might affect its results. For instance, there are many ways of media reporting, so some of the details might be left out in collection of news data. To compound matter, the study only used a single database, so it is quite possible that some news would not be included, which would result in underestimation of the news coverage amount. Also, false news could be deliberately released by the companies issuing the stocks in order to promote their stocks and draw more eyes from investors. Since the database used by this study does not distinguish veracity of the media data, the study therefore could not judge if the results would have any variance from the veracity of media coverage.

\section{ACKNOWLEDGEMENT}

This study was supported by Asia University under Grant No. 100-asia-46. We acknowledge the helpful comment and suggestions from the anonymous reviewers. 


\section{REFERENCES}

Ahern, K.R. and D. Sosyura (2012). Who Writes the News? Corporate Press Releases during Merger Negotiations. Journal of Finance, forthcoming.

Antweiler, W. and M.Z. Frank (2004). Is All that Talk Just Noise? The Information Content of Internet Stock Message Boards. Journal of Finance, 59, 1259-1294.

Antweiler, W. and M.Z. Frank (2006). Do US Stock Markets Typically Overreact to Corporate News Stories? Working Papers.

Barberis, N., A. Shleifer and R. Vishny (1998). A Model of Investor Sentiment. Journal of Financial Economics, 49, 307-343.

Barber, B.M. and T. Odean (1998). The Courage of Misguided Convictions. Journal of Financial Analysts, 55(6), 41-55.

Barber, B.M. and T. Odean (2001). Boys will be Boys: Gender, Over-confidence, and Common Stock Investment. Quarterly Journal of Economics, 116, 261-292.

Barber, B.M. and T. Odean (2008). All that Glitters: The Effect of Attention and News on the Buying Behavior of Individual and Institutional Investors. Review of Financial Studies, 21(2), 785-818.

Barber, B.M. and T. Odean (2011). The Behavior of Individual Investors. Working Paper.

Black, F. (1986). Noise. Journal of Finance, 41(3), 529-543.

Borden, M.J. (2007). The Role of Financial Journalists in Corporate Governance. Fordham Journal of Corporate \& Financial Law, 12(2), 6-129.

Brennan, M.J., N. Jegadeesh and B. Swaminathan (1993). Investment Analysis and the Adjustment of Stock Prices to Common Information. Review of Financial Studies, 6(4), 799-824.

Buskirk, A.V. (2006). Capital Market Effects of More Frequent Disclosure. Working Paper.

Carroll, C.E. and M. McCombs (2003). Agenda-Setting Effects of Business News on the Public's Images and Opinions about Major Corporations. Corporate Reputation Review, 6(1), 36-46.

Chan, W.S. (2003). Stock Price Reaction to News and No-news: Drift and Reversal after Headlines. Journal of Financial Economics, 70, 223-260.

Chen, C.C. and J.R. Meindl (1991). The Construction of Leadership Images in the Popular Press: The Case of Donald Burr and People Express. Administrative Science Quarterly, 36, 521-551.

Cutler, D.M., J.M. Poterba and L.H. Summers (1989). What Moves Stock Prices? Journal of Portfolio Management, 15, 4-12.

Da, Z., J. Engelberg and P. Gao (2011). In Search of Attention. Journal of Finance, 66(5), 14611499.

Dougal, C., J. Engelberg, D. Garci'a and C. Parsons (2011). Journalists and the Stock Market. Working Paper.

Dyck, A. and L. Zingales (2003). The Media and Asset Prices. Working Paper.

Engelberg, J. and Parsons, C. (2011). The causal impact of media in financial markets. Journal of Finance, 66(1), 67-97.

Engelberg, J., C. Sasseville and J. Williams (2012). Market Madness? The Case of Mad Money. Journal of Management Science, 58(2), 351-364.

Fang, L. and J. Peress (2009). Media Coverage and the Cross-section of Stock Returns. Journal of Finance, 64(5), 2023-2052.

Foster, F.D. and S. Viswananthan (1990). Variations in Trading Volume, Return Volatility, and Trading Costs: Evidence on Recent Price Formation Models. Journal of Finance, 48(1), 187-211.

Holden, C.W. and A. Subrahmanyam (1992). Long-lived Private Information and Imperfect Competition. Journal of Finance, 47(1), 247-270. 
Islam, R. (2002). The Right to Tell: The Role of Mass Media in Economic Development. Washington, D. C., The World Bank.

Kim, Y. H. and F. Meschke (2011). CEO Interviews on CNBC. Working Paper.

Klibanoff, P., O. Lamont and T.A. Wizman (1998). Investor Reaction to Salient News in Closedend Country Funds, Journal of Finance, 53, 673-699.

Kovács, E., B. Dömötör and H. Naffa (2011). Investment Decisions in Crises - A Study of Private Pension Fund Investments. Acta Oeconomica, 61(4), 389-412.

Kyle, A.S. (1985). Continuous Auctions and Insider Trading. Econometrica, 53, 1315-1336.

Li, M. and S. Yen (2011). Re-examining Covariance Risk Dynamics in International Stock Markets Using Quantile Regression Analysis. Acta Oeconomica, 61(1), 33-59.

Liu, L.X., A.E. Sherman and Y. Zhang (2007). Media Coverage and IPO Underpricing. Working Paper.

McCombs, M.E. and D.L. Shaw (1972). The Agenda-setting Function of Mass Media. Public Opinion Quarterly, 36, 176-187.

Nofsinger, J.R. (2001). The Impact of Public Information on Investors. Journal of Banking and Finance, 25(7), 1339-1366.

Shiller, R. (2001). Exuberant Reporting: Media and Misinformation in the Markets. Harvard International Review, 23, 60-65.

Sherman, A.E. and S. Titman (2002). Building the IPO Order Book: Underpricing and Participation Limits with Costly Information. Journal of Finance, 65, 3-29.

Shieh, C.J. (2014). The Impacts of Social Network on Operating Performance in Microenterprises. Acta Oeconomica, 64 (Supplement 2), 229-242.

Stephens, C.P. and M.S. Weisbach (1998). Actual Share Reacquisitions in Open-market Repurchase Programs. Journal of Finance, 53, 313-333.

Tetlock, P.C. (2007). Giving Content to Investor Sentiment: The Role of Media in the Stock Market. Journal of Finance, 62(3), 1139-1168.

Tetlock, P.C., M. Saar-Tsechansky and S. Macskassy (2008). More than Words: Quantifying Language to Measure Firms' Fundamentals. Journal of Finance, 63(3), 1437-1467.

Vega, C. (2006). Stock Price Reaction to Public and Private Information. Journal of Financial Economics, 82, 103-133. 